\title{
The Spiritual Knowledge in the Era of Globalization
}

\author{
Ioan Stinghe
}

\begin{abstract}
Tackling the knowledge supposes the study of a phenomenon which has over passed civilizations and in the same time an actual phenomenon, with great perspectives of future development. Because knowledge is a phenomenon with a big complexity, based on the relation of humans with divinity, in this article we will approach knowledge from the perspective of the necessity of recovering the sacred and of the interconnection of human with the divine through the transcendental experience, as a reliable source for the future and development of knowledge. We will briefly analyze globalization, for updating the reference frame and for being able to emphasize the knowledge dynamics in a society which needs, more and more, integration in the harmonious and rational order of the Universe.

KEY WORDS: knowledge, sacred, globalization, revelation, theology.
\end{abstract}

\section{Introduction}

Generation after generation, people wanted to find out, to Junderstand and to know the fundamental laws of life, the universal order and harmony, people relation with the environment and of course their role and purpose on this planet.

According to Earle Babbie, the human being cannot surpass his human condition, in order to see the world and to understand 
it the way it truly is, independent of the human point of views, he states:

While the modern perspective recognizes the inevitability of the human subjectivity, the post-modern perspective suggests that there isn't an "objective" reality. There are only our subjective perspectives. ${ }^{1}$

The unquestionable reality of human limits, which affects the knowledge domain too, puts humanity in the impossibility of knowing and understanding the mystery of the Universe. In the experience of research, each approach involves a starting point. It is necessary to build up a base for formulating the doctrinaire models, the concepts, and for reviewing the hypothesis. According to Dagobert D. Runes, Epistemology is "the branch of philosophy which investigates the origin, the structure, the models and the validity of knowledge."

The first step in creating an epistemological base can be realized through the interaction between ration and reality, in the moment of the contact with the truth and reality. The first obvious source of the contact with the truth is the sensorial perception called Empiricism, followed by the rational criterion named Rationalism, than by the concept a priori and Intuitionism. For the Christians there is another epistemological principle as a source for truth called Revelation. Because these epistemological principles require faith they are suppositions. The process of knowledge contains techniques, instruments, methods and ways which make use of a specific language.

As the academician Vasile Stănescu states, scientific knowledge

presents a philosophical perspective of experience and one specific to the different scientific branches. The theological knowledge has its origin in the transcendental and it has as its base the Creation, the Scripture and the Revelation.

"The knowledge, along with the information, represent the most important vectors of the technical-scientific progress, determining the entire socio-human activity, in the passing from the post-industrial civilization to the civilization based on knowledge." 3 


\section{Knowledge, Science and Consciousness}

The aim of science is first of all moral. It implies a commitment toward a Supreme authority, which transcends us, without harming the objective character which every research of the truth has to endure, and without disregarding the objective application of the scientific methods. This commitment can be taken only towards God, the only source of knowledge and love, the only model of knowledge and love which inspires us. The purpose of the authentic science is the knowledge of God:

This is what the lord says: "Let not the wise boast of their wisdom or the strong boast of their strength or the rich boast of their riches, but let the one who boasts boast about this: that they have the understanding to know me, that I am the Lord, who exercises kindness, justice and righteousness on earth, for in these I delight. (Jeremiah 9,23-24)

From this statement of a supreme truth we understand that the human being who acquired this knowledge will exert the good will, righteousness and justice, doing the divine actions.

The contemporary science, due to the fact that it doesn't have a well-defined moral purpose, has alarmed the scholars. Many scientists rise from their scientific numbness, and find themselves, together with the entire humanity, in front of the thermonuclear danger. Why? Because seduced by his discovery, the scholar has forgotten about the One that has given him science and determined his purpose.

The contemporary scientist, who has forced the limits of the determinism, letting a Creator God to appear at the horizon, has to continue the way further on, and admit in front of God the freedom that He has given to the matter by energy and to human by free will. The contemporary scientist has to pass the border between Knowledge and Love, and to acknowledge that the World Creator is the Master of the Universe, his personal god, The Alive God in front of who he is responsible. 
In his autonomy toward God, he has come to be dependable on human being, assertive towards society and state. He has aspired to dominate the state and society, then he has broken off from the state and society and felt isolated, and then dependent on them. In this way, the scholar without God has come to think of himself as God. ${ }^{4}$ Science manifests its domination throughout the entire humanity; it has marked the way of life of the individual and of the society. It has determined radical changes during the last historical decade, establishing the supremacy of applicable science under the form of technocracy.

The occidental human being created Technocracy, imposing it to the entire world, even though for the moment it is not accessible to the entire mankind. This science is the result of the occidental civilization, produced by the occidental culture, based on an occidental Christian culture. Naturally, the following question comes to mind:"how it is possible for a science which does not unify "knowledge" with "love", to be born from the Christianity?"

The modern science developed from the Greek philosophy, which was adopted by the occidental Christianity too. Alexandru Şafran in "Jewish Ethics and modernity" states:

The organic unity of the Jewish monotheism-the communion of the spirit with the knowledge, the insertion of love into the law, the joy of this world and the preparation for the future world, the association of the civilization to the culture, the integrity of the sacred and profane-was remote in Christianity. ${ }^{5}$

This separation gave birth to a Christian religion and a Christian civilization in the occidental society, which came to be grounded on an antiscientific religion and an antireligious science. Thus, over the years, science and religion formed two distinct entities which have learned to live together, adopting a kind reciprocal attitude, reaching to a solution of compromise, called the historical method of Christianity.

In this way two worlds were established into the Universe, in which by far, the science helped by the technique is predominant, 
in a world situated on the doorstep of a new era. From now on, this two cannot cohabit anymore and tolerate an agreement based on hypocrisy. The Christian religion cannot handle the modern science accession.

The danger of threatening hovers over the humanity. For pulling aside this threat of the endangerment of human species through science, the human, parallel with the effort of the scientists, should exert a moral effort and dominate the self. The human being has to point his thinking toward the sky and remind himself that God created everything and offered His Wisdom and spread His Blessings to His creatures, for them to enjoy and be happy.

Nowadays, the scientist is asked to accomplish his sacred mission, as a man conscious of the wisdom he posses, and by his responsibility toward the Creator, toward humanity and creation, manifesting "knowledge" and "love". In this situation, when the religion is ready to surrender in front of the idolatrous scientific materialism, the Judaic conception about science can indicate the route of life and freedom. ${ }^{6}$

A presentation of the knowledge becoming, contrasting and relevant for our time belongs to the academician Mihai Drăgănescu:

The society of consciousness will be born from the society of knowledge, in this way the support offered by the society of knowledge, with the vectors which have constituted it and maintain it, can be considered like being one of the vectors of the society of consciousness. Beside the technologies taken from the society of knowledge, like the internet, the artificial intelligence, nanotechnology, technological vectors specific to the society of consciousness, there would be artificial technologies and of biotechnology for transforming the human species, the conscious internet, the technologies for actions at a big distance in the interplanetary space of the Universe, as well as technologies for actions in the profound reality, in order to produce effects of phenomenological communication through the substratum of the profound existence (which in a natural way it is done with an infinite speed), or for the phenomenological-structural effects, producing energetic 
consequences or on the substance in its spatial-temporal reality. The society of consciousness will have functional vectors too, like knowledge (of biggest importance being the fundamental knowledge of the existence), spirituality, management and economy (of the society of consciousness), education (not only of human, but of everything it is consciousness for continuing with the good past of the mankind), culture (with the same observation as in the above mentioned case). The society of consciousness is being prepared from these days. ${ }^{7}$

\section{A Glance in the Twentieth Century}

We live in the time when the mutations and the oppositions, the searching and the reversals are multiplying, a time of obsolescence and discontinuance, a time of alienation from God and people. We see from the distance the difference between people, confronting in a world initiated on the road of standardization, determined by the development of technology and information.

The concern and fear take hold of the architects of the industrial consumer society. Their depression increases as the society, more and more organized, enslaves the individual until he comes to be insensible to the paradoxes which results from the technical development. The rationality rises like a fantastic sun which makes the opacity of the creatures transparent. This statement of the rationality, coming out from Philosophy, which is the originality of the era, is not the conquest of the eternity promised to the Logos by the antique wisdom.

We witness a process of leveling through a civilization, through language, literature and art. The intelligible can be seen in the print left in things by the work of the mortals, in the perspectives opened by citizens and by empires predestinated to collapse. As a result, in the intelligence drama, the human being is an actor before being a thinker. The individual's destiny consists in playing, at the establish times, a role in the rationality's drama, but not in the understanding of this drama. What matters is to be authentic, but not to be in truth, 
to engage, but not to know. The art, love, action, conquer theory. The talent values more than wisdom and self-control.

The major importance that the transformation of things and societies has for humans, and the attention given by the established religions to the transformations of life on earth, define our time. Never had the religious and the profane been so separated. From the perspective of the progress and the knowledge development, the twentieth century brings many transformations in the management and features of knowledge. For example, the closeness of the science to the practical domain, through the way of organizing and unrolling the scientific research with an applicable purpose.

In the twentieth century we distinguish certain features of science which had a positive impact on the development of knowledge:

- highlighting the synthetic way of thinking, which leads to a new integral vision and a coherent image of the world, diminishing the science fragmentation

- extending the mathematical way of thinking in all the fields of knowledge

- integrating the historical perspective in the effective scientific creation and construction

- increasing the role of theoretical thinking in the elaboration of knowledge and of constructive approach

- increasing the weight that the applicable science has in the research, and the impact of the modern techniques on the scientific thinking. 8

In the twentieth century we witness how the progress and the development of modern science have influenced the economic, cultural and social factor and the technological development. The step resulted from the science and technology development has revealed the limits of the scientific rationalism for validating the knowledge, and the reality that the scientific research falls behind the technologic progress.

The twentieth century is the period in which the theoretical and methodological development of science takes place. In this context, 
the philosophy of science through more explicative models leads to the creation of a new epistemological profile of modern science. We can state that by passing to a new conceptual level in the twentieth century, the research determined the adaptation and perfection of models and of the investigation ways and techniques.

In this way it has come to the necessity of inter and multidisciplinary cooperation, having as a result the synergism and co-participation, in order to be able to give answers to the more and more complex issues with globalizing effects.

\section{The Twenty-First Century or the Globalization Era}

The actual tendency, based on Informatics, Robotics, Micro processing, Biotechnology and Telecommunications, is towards the applicable science which leads to the replacement of the scientific research with the research promoted by the society. This new revolution determines the appearance of the informational society, which paves the way for the society of knowledge, as a condition of the progress.

In this context, G. Martinotti defines knowledge as "an interconnected system of information and data." ${ }^{\prime 9}$ system of promoting knowledge is created, by integrating education, research and innovation, created from the interconnection and cooperation of higher education institutions, public research institutes and companies. This configuration in the informational society receives a bigger importance, in the context in which the production and spreading of knowledge gains a global character.

The process of knowledge has a cumulative character. From a historic perspective the humanity finds itself on a new threshold in the evolution of knowledge. We have to notice the superior value of the level of knowledge, stated by the awareness of this phenomenon worldwide, as a potential solution for the future problems of the mankind.

The informational society creates a global vision, stimulates through communication the interdisciplinary and interconnectivity, having as a result the synergism, co participation and responsibility 
in a plan, and the emergence of knowledge in another plan. The eminent academician Vasile Stănescu, sustains the creation of the society of consciousness, as being the central idea based on knowledge, with a big potential for change in the global society of future. Referring to the necessary transition he states that:

Passing from an informational society represented by the internet to the society of knowledge and tomorrow to the society of consciousness, involves the elaboration of a system of knowledge, characterized by continuity, stability and sustainability, specification of the access to information and existent electronic services and of spreading the information in all the activity domains. The knowledge and consciousness are the great values of the future. ${ }^{10}$

Alexandru Şafran, declared in "The Jewish Ethics and modernity,"

The science is on the verge of a new era. Which is its source? The human being who divines himself. Which is its object? An idol fabricated by itself, a religion which it respects dogmatically. Which are the signs of the new era? These shake up the rational divinity of human being; they broke its idols and destroy its rituals. The intellectual and the pure reasoning is not the only source of science, state the new representatives of science. It is admitted that the world was created and the origin of life is searched, but it remains hidden for our view. They try to create life but without success. We act in a created world, we transmit it, we transform it, but we cannot create it. In this way we reach God. ${ }^{11}$

The human independence towards God, the human in the centre of the culture, the separation between Theology, Science and Culture, reevaluation and changing of human life values, are just a part of the steps which have lead to the replacement of the divine with the human. The entire socio-historical development of the mankind, knowledge mainly, it is based on the relation between God and human. The religion (religo/religare) is not only a part of history; it 
is constituted as a philosophical system and cultural phenomenon, with effects in the social behavior.

Theological knowledge as a way of knowing God, has its origin in a reality superior to human intelligence, in transcendental, based on the Creation of the Universe, "ex nihilo", through His Logos and Divine revelation. The Orthodox Theological knowledge according to "The Dogmatic Theology" can be, after its way of expression, affirmative or negative, can be kataphatic or apophatic. Theology uses these names with the sense of ways of religious knowledge and ways of expressing this knowledge; a positive and a negative way, like kataphatic theology and apophatic theology. Furthermore, according to this book, "the highest and the broadest knowledge of God is by true belief, warmed by love, which is the greatest virtue." (I Cor. 13: 13)

Because "God is Love (I Joan 4: 16) and this being, He comes into the world He loves (Joan, 3: 16), and "we, love God, because He loved us first" (I Joan 4: 19) and, loving Him, we raise at Him because "love is from God and anyone who loves God and knows God. The one who does not love does not know God." (I Joan 4: 7-8), but "the one who lives in love lives in God and God lives in him "(I Joan 4: 16).

From all these does not result, like one can notice taking into account the helplessness of grasping our knowledge in the essence of the godlike things, that in general we would know too little from Those of God, meaning from the being and His attributes, but, instead, we know more if we struggle properly to come forward on the path of knowledge offered to us through the natural and supernatural Revelation and if we strain to transfer it to life." 12

The character of the theological conduct determines the social behavior of people. The unsacred human society needs the revelation of the sacred, by transcending from a spiritual level of the current historic reality to a spiritual level with a par historical perspective, on the oath of the divine revelation.

The process of globalization affects all the existential domains, including Theology. Theology had its role in the secularization of human society. The secularization and the atheism have oriented against confession, when divinity was no longer a personal God, loving, but He appeared as The Great Metaphysic, distant, and 
incapable of manifesting concern for the human being. Our time is marked by the absence of God, in the sense that people do not perceive any more the presence and the work of God into the world and they do not understand the content of the reality of God. In this way the possibility of the knowledge of God is damaged.

Many theologians understood the Theology challenge of giving an answer regarding the divine existence and presence in the globalization process, in a moment marked by the breaking off from its own roots. Even though the results were unwanted in a theological plan, we notice a positive fact: the secularization determined a reposition of the Theology, giving it a new starting point in approaching divinity.

The eminent Lewis A. Drummond highlights the fact that Rationalism and Empiricism uncover many aspects of reality because there is a fundamental rationality into the universe, thus, being in the impossibility of studying thoroughly the supra rational divinity, even though He is the base of the fundamental rationality. That is why God reveals His purposes that He has with the mankind through His Son Jesus Christ, revelation which becomes "the final test of all the theological claims."13

Habermas, one of the most preoccupied contemporary philosophers of the solidarity between Philosophy and Theology, did not avoid recognizing "the parallelism of the answers" of Philosophy and Theology, stating how indebted he is to the theologians. He says:

Philosophy struggles here, and in the problem of theodicy, not only to come closer to the semantic potentiality which are kept in the religious tradition; it can come to help a theology that would want to clarify the self understanding of the Christianity and of the Church regarding the cultural pluralism and of the visions of the world. ${ }^{14}$

Theologian Hans Kung concludes: "In this way we are dealing with a post-euro-centrism and we have to expect a post-imperialist global society, this can mean truly united nations, which cooperate on an international level. On an economical plan an eco-social 
market economy is developed and on a political plan, a postindustrial society is developed, based more on service delivery and communications. Culturally, we are on the route to a culture with a greater pluralistic-holistic orientation, an interreligious society, ecumenical, multi-confessional. "15

\section{Conclusions}

At the beginning of the twentieth century, the postmodernist endeavor generated a reevaluation process of the basic concepts, by historical denial and critique. After this undertaking, what was considered obsolete comes forward again. The domains which reveal the presence and the effects of the belief in the divine, the culture, social and others, prove these changes. The prognosis of the disappearance of religion proved to be false.

Religion turns back in the post-secular society, demonstrating that it has survived rationalization and demythologization. In the contemporary Philosophy there appeared religious terms, recognizing the fact that The Law of God is above all the human laws, it is a sign that religion finds its right place in the life of the mankind. Confronting Theology with the challenge of the secularism and globalization, gave the chance of giving up a false sacrality in the domain of the theological discourse and of the religious practice.

The rethinking and restating of the theological truth helped the reaffirmation of the possibility of meeting the divine with the human, favoring the development of authentic knowledge, which supports progress and development of human society. Knowledge itself depends on the level of enlightenment reached by the expert. That is why the wisdom or the knowledge has its roots in God, from where it flows towards all the levels of the creation. The wisdom or the enlightenment is the agent of a threefold universal rhythm: mone, proodos, epistrophe; it resides in God, comes from Him, and turns back to God.(the Theology of Grigorie de Nazianz)

We have to mention God more often than we breath, according to the word: „to be pondered on day and night” (Ps. 1, 2) and „God be blessed on all times", but with precaution and not anywhere and 
anytime, because "each thing has its time." "The Descendent God became human as for me to become God as He became human." By extension, the divine knowledge became human knowledge for it to become again divine knowledge. This is the pulse of a gnoseology, strongly anchored in ontological structures, resized after the physiognomy per se, which is God."(After the Theology of Grigorie de Nazianz) ${ }^{16}$

NOTES

${ }^{1}$ Earle Babbie, Practica Cercetării Sociale, (Editura Polirom, Iași, 2010),38.

${ }^{2}$ Dagobert D. Runes, ed., The Dictionary of Philosophy (Patterson, N. J.: Littlefield, Adams and Co., 1961), 94.

${ }^{3}$ Vasile Stănescu, Globalizarea spre o nouă treaptă de civilizație, (ClujNapoca, Editura Eikon, 2009), 61.

${ }^{4}$ Alexandru Şafran, Etica evreiască şi modernitatea, (Bucureşti, Editura Hasefer, 2005),185.

${ }^{5}$ Ibid.

${ }^{6}$ Alexandru Şafran, Etica evreiască şi modernitatea, (București, Editura Hasefer, 2005),189.

${ }^{7}$ Vasile Stănescu, Globalizarea, spre o nouă treaptă de civilizație, (ClujNapoca, Editura Eikon, 2009), 72.

${ }^{8}$ Ştefan Georgescu, (coord.), Mircea Flonta, Ilie Pârvu, Teoria cunoaşterii ştiințifice,(București, Editura Academiei R.S.R., 1982), 33-36.

${ }^{9}$ Giovanni Martinotti, Interdisciplinarity and the Organization of Knowledge in Europe, (Cambridge, 1997), 166.

${ }^{10}$ Vasile Stănescu, Globalizarea spre o nouă treaptă de civilizație, (ClujNapoca, Editura, Eikon, 2009), 73.

${ }^{11}$ Alexandru Şafran , Etica evreiască şi modernitatea, (Bucuresti, Editura Hasefer, 2005),151.

${ }^{12}$ Isidor Todoran, Ioan Zăgrean, Teologia dogmatică, (București, Manual pentru seminariile teologice, 1991), 94-96.

${ }^{13}$ Lewis A. Drummond, Mesajul Crucii, $O$ teologie contemporană a evanghelizării, (Oradea, Editura Institutului Biblic „Emanuel”, 2001), 45.

${ }^{14}$ Andrei Marga, Religia in Era Globalizării, (București, Editura, Academiei Române, 2014), 65-66.

${ }^{15}$ Hans Küng, Iudaismul, (Bucureşti, Editura, Hasefer, 2005), 481.

${ }^{16}$ Ioan-Gheorghe Rotaru, Aspecte antropologice în gândirea patristică şi a primelor secole creștine (Cluj-Napoca, Presa Universitară Clujeană, 2005), 124-129. 


\section{BIBLIOGRAPHY}

Babbie, Earle. 2010. Practica Cercetării Sociale, Iași: Editura Polirom.

Drummond, A.Lewis. 2001. Mesajul Crucii, O teologie contemporană a evanghelizării. Oradea: Editura Institutului Biblic „Emanuel”.

Georgescu, Stefan, Mircea Flonta si Ilie Pârvu (coord.) 1982. Teoria cunoaşterii ştiințifice. București: Editura Academiei R.S.R..

Küng, Hans. 2005. Iudaismul. București: Editura Hasefer.

Marga, Andrei. 2014. Religia in Era Globalizării. București: Editura Academiei Române.

Martinotti, Giovanni. 1997. Interdisciplinarity and the Organization of Knowledge in Europe. Cambridge.

Runes, D. Dagobert. 1961. The Dictionary of Philosophy Patterson. N. J. Littlefield: Adams and Co.

Rotaru, Ioan-Gheorghe. 2005. Aspecte antropologice în gândirea patristică şi a primelor secole creştine. Cluj-Napoca: Presa Universitară Clujeană. Hasefer.

Şafran, Alexandru. 2005. Etica evreiască şi modernitatea. București: Editura

Stănescu, Vasile. 2009. Globalizarea, spre o nouă treaptă de civilizație. Cluj-Napoca: Editura Eikon.

Todoran Isidor si Ioan Zagrean. 1991. Teologia dogmatică. Manual pentru seminariile teologice. București. 